\title{
Measuring the Impact of Russian Privatisation at the Turn of the Century: An Introduction to the Symposium
}

\author{
SAUL ESTRIN
}

Centre for New and Emerging Markets, London Business School, Regent's Park, London NW1 4SA, UK. E-mail: sestrin@london.edu

In this paper, we introduce our survey of 437 Russian industrial enterprises, 1997-1999. We gathered data on enterprise performance, both qualitative and quantitative, and four determining features of the Russian industrial environment ownership structure (state, insider, outsider); competition (domestic and international); governance (ownership versus control); and financial constraints. The Special Issue contains papers explaining the relationship between each of these factors and enterprise performance. In the final paper, we consider the effects jointly, and their interactions. Survey methodology is outlined in the Appendix. Comparative Economic Studies (2003) 45, 109-116. doi:10.1057/palgrave.ces.8100011

Keywords: privatisation, Russia, firm performance

JEL Classifications: O12, P31, L10

\section{INTRODUCTION}

Just as the literature on communist economics focused disproportionately on the Soviet Union (see eg Gregory and Stuart, 1986), Ellman, 1989), so research on the transition economies has placed emphasis on the way that the reform process has unfolded in Russia (see World Bank, 1996). This is probably because of the geo-political significance of the Russian Federation, including its size, military capacity and resource endowment, as well as its political leadership across the region. However, transition in Russia has always been viewed as being likely to prove more difficult than in the small, relatively more open and reform-minded economies like Hungary or Poland (see Blanchard et al., 1991; Portes, 1993). The huge scale and long communist traditions of Russia made the obstacles to reform seem almost insurmountable: a view apparently confirmed when the reform process appeared to 
founder at the time of 1998 financial crisis (see EBRD, 1999). The economic outlook for Russia is currently perceived in a more positive way (see Hanson, 2002), in no small part because of the relatively high oil price and its positive impact on economic growth and the government's fiscal position. However, even the most recent analyses suggest that country still has some way to go to eradicate profound problems with corporate governance, as well as with broader institutional development (see EBRD, 2002). An evaluation of progress in these areas at the enterprise level is the subject of this Special Issue. $^{1}$

We use evidence from a survey of privatised Russian enterprises to chart progress in corporate governance, the business environment and company performance from the time of privatisation until 2000. Reforms in Russia since 1992 have centred upon the privatisation process (see Boycko et al., 1995), which transferred ownership in tens of thousands of companies across the country (see Earle and Estrin, 1997). Initial evidence about the impact of this privatisation, however, has been worrying. While ownership was successfully shifted away from the state to the private sector, the emergence and entrenchment of widespread insider ownership, combined with the poor development of capital market institutions (see EBRD, 1999), meant that privatisation had proved to have only limited impact on company performance up until the mid-1990s. This finding was deduced in a number of studies (eg Blasi et al., 1997; Earle and Estrin, 1997; Estrin and Wright, 1999; Brown and Earle, 2001) and is the standard conclusion in several authoritative surveys (eg Nellis, 2000; Djankov and Murrell, 2002).

However, the conclusion that Russian privatisation has had little effect on enterprise performance was derived from data collected only a few years after the ownership changes. This timing was not ideal because other things were changing in the economic environment simultaneously. For example, this was also the period when firms were seeking to recover from disorganisation: the collapse of supply relationships governed by a central planning process but prior to the establishment of business to business relationships intermediated through the market (see Blanchard and Kremer, 1997). Data on enterprise performance were also noisy because of widespread use of barter in

\footnotetext{
${ }^{1}$ This special issue has benefited from the work of the entire research team: Alan Bevan, Boris Kuznetsov, Mark Schaffer, Manuela Angelucci, Julian Fennema and Giovanni Mangiarotti, as well as research assistance by Maria Bytchkova. The papers were presented at a workshop at the Bureau of Economic Analysis in Moscow in 2001. A previous version of this Special Issue was published 'The Determinants of Privatised Enterprise Performance in Russia', Centre for New and Emerging Markets DP no. 3193. The advice, encouragement and patience of Jeffrey Miller is also gratefully acknowledged. Financial support from the Centre for New and Emerging Markets and of the UK Department for International Development is also gratefully acknowledged.
} 
transactions (see Ledeneva, 1998). Given the long heritage of communism and planning, some of these studies were probably undertaken too soon to deduce definitive conclusions about the impact of the new ownership, incentive and information systems on the performance of companies. ${ }^{2}$

We were therefore encouraged to undertake a new large-scale enterprise survey, which drew inspiration from the study undertaken by the World Bank in 1994 (see Commander et al., 1996). ${ }^{3}$ The survey was organised through the Russian Bureau of Economic Analysis between mid-1998 and 1999, and was carefully constructed to be a random sample within the population of firms considered. The sample was relatively large - 437 firms - but given the size of Russia still needed to be stratified to six two-digit manufacturing industries; to firms employing between 100 and 5,000 workers; and to 11 regions within the four main economic zones. Comparison with Goskomstat data (19901999) confirms that our sample is reasonably representative of the relevant national patterns. Sampling methodology and comparisons between the sample and the population are presented in the Appendix.

We based our study on the following organising framework. Enterprise performance in transition economies has been associated in the literature (see eg Djankov and Murrell, 2002) with four broad aspects of the economic environment: ownership (state versus private; insider versus outsider); governance (ownership versus control); market structure and competition (domestic and international); and financial constraints (eg access to equity or debt). Much of the questionnaire addresses ways to measure enterprise and the business environment.

One can conceive of enterprises, pre-reform, as operating away from the profit maximising equilibrium in two senses. First, levels of output, employment and perhaps capital would exceed those implied by a profitmaximising rule, because of planners' preference for gigantism (see eg Bennett, 1989). Second, firms would operate within their production possibility frontiers because of weak or inappropriate managerial incentives and poor monitoring by owners (see Ellman, 1989). The 'Washington consensus' reform package - stabilisation, liberalisation and privatisation can be viewed as changing the economic environment in which enterprises operate in the following ways. Privatisation would fundamentally alter the balance of ownership away from the state and towards the private sector. This

\footnotetext{
${ }^{2}$ A point stressed in the papers themselves, see for example, Earle and Estrin (1997, Introduction).

${ }^{3}$ There have been other surveys of Russian firms in the past 3 years, on a variety of issues including innovation, corruption and the new-market economy. Few have yet returned to the fundamental theme of the determinants of company performance, based around a large-scale random survey, though see Brown and Earle (2001).
} 
112

should lead to improved enterprise performance, in the sense of higher TFP, because of enhanced monitoring of managers and sharper managerial incentives (see Vickers and Yarrow, 1988; Nickell, 1996; Megginson and Netter, 2001). It should also lead to profit maximising behaviour, and, given the starting conditions, therefore probably a reduction in output and factor inputs.

As we have seen, the situation was not quite so straightforward in Russia. Privatisation was mainly to insiders - workers and managers - whose incentives to improve performance were more ambiguous than those of outsiders (see Earle and Estrin, 1996). Indeed, perhaps the fundamental problem for reform in Russia has been that the privatisation process started by giving control to managers. The majority owners were dispersed insiders (workers) or outsiders (investment funds, former workers, banks). Privatisation did not give the managers sufficient ownership - typically less than $10 \%$ of the total stock at the outset - to motivate improved performance (see Earle and Estrin, 1997); rather the incentives to restructure and improve profitability were often outweighed by incentives to do nothing or even to expropriate assets (see Stiglitz, 1999).

This was perhaps an inevitable starting point for private ownership in a country with limited private savings and a long tradition of communism (see Boycko et al., 1995). The crucial question is whether the ownership structure began to evolve through market forces towards one more conducive to enhance corporate governance and improved performance. Our survey instrument was designed to allow us to address issues of ownership and ownership evolution in some detail, and relate these to a variety of measures of company performance, both quantitative, such as economic or financial performance (productivity, profitability), and qualitative indicators of restructuring activity (See Estrin et al., 1995). We also explore indicators of corporate governance, including managerial turnover.

At the same time, reforms will influence the economic environment in which firms are trading. Stabilisation will provide a reduction of risk and clarity of economic signal to managers. Liberalisation impacts on enterprise performance by enhancing the competition faced by firms in their product markets. Even when corporate governance is weak, enterprises can be forced to improve performance by tough competition in their domestic or international markets. The effect of this on company performance, of course, depends in part on ownership structure.

However, restructuring is likely to be an expensive activity, requiring investment in new technologies, methods and systems. The capacity of firms to finance these activities internally, and the availability of resources from capital markets, is the final area of analysis. Much of the literature on 
restructuring and enterprise performance implicitly assumes that capital is available at a fixed interest rate with infinitely elastic supply. In practice, this was not true in Russia - capital was scarce and allocated more by rationing than by price. In the Russian literature, this has been regarded as a major constraint on economic development. It also relates to issues of ownership and governance because management will not be able to raise additional funds from the owners if shareholders are insufficiently protected. This may lead to binding financial constraints on enterprise behaviour, which can hold back restructuring and influence total factor productivity and company performance.

Our main purpose in this Special Issue is therefore to use the data from our sample to look separately at these influences on company performance. We first consider the effects of ownership and competition on enterprise performance, and then of corporate governance by investigating the determinants of CEO turnover. The third paper examines the financial environment and its impact on restructuring and firm performance. In the concluding paper, we bring together our findings to evaluate as a whole the determinants of enterprise performance in Russia in 2000.

The first paper, by Estrin and Angelucci, examines the effect of competition and its interaction with ownership structure on improvement in enterprise performance in Russia. The survey finds that ownership of Russian firms has been moving away from insiders to outsiders in the second half of the 1990s. Within the insider group, ownership has become more concentrated in the hands of managers, who have increased their control by almost $30 \%$. Using a variety of measures of performance, the paper finds that insider-owned firms have slightly higher productivity and a slightly smaller fall in employment and investment share. Insider-owned firms more often undertook 'deep' restructuring. However, none of these differences are significant at even a 90\% level, implying that ownership change has still not begun to have a significant effect on quantitatively measured company performance by 2000. However, the paper does provide evidence of a positive association between qualitative measures of restructuring firm and competitive pressures. Firms in highly competitive markets undertake more deep restructuring than those in highly concentrated markets. The paper confirms a significant joint role of private ownership and competition; competition has a larger effect on performance in privately owned firms than in state owned ones.

The issue of corporate governance and accountability of Russian managers is examined by Alexander Muravyev by studying the dynamics and determinants of CEO turnover, which is found to approach $12 \%$ per annum. This rate places Russia above developed countries but below some 
transition countries. CEO turnover is found to be guided by the same forces as in developed countries. Crucially, company performance does play a role in determining CEO's tenure, as managers whose companies under perform their respective industries face a higher probability of replacement. This relationship is strengthened by the presence of a regional government as an owner or by a small size of the board. However, there is a difference in turnover, which depends on the ownership of the firm. The paper shows that insider ownership inhibits CEO turnover, while both state and private outsider ownership are associated with higher turnover rates.

The financial environment is the subject of the third paper by Bevan and Fennema, which investigates the relationship between finance, restructuring and performance. The paper identifies the extent to which Russian enterprises are financially constrained in access to bank loans, state support and equity markets. It then analyses how financial constraints are affected by the firm's size, location and industry sector. The results confirm that size, region and industry matter in obtaining finance: small firms are more financially constrained then large and medium ones; regions such as Moscow city, St Petersburg, Nizhny Novgorod and Volgograd face lower financial constraints, as do the food and chemical industries. The paper finds that there is a positive correlation between barter and credit constraint and a negative one between investment and financial constraints, but there is only limited evidence to support the notion that financially unconstrained firms are better at restructuring.

The final paper in the Special Issue by Bevan and Estrin brings together the analysis by estimating regressions linking enterprise performance to the four categories of determinant examined in the papers: ownership, governance, competition and financial constraints. These independent variables are entered interactively to control for the possibility that pressures on firms to improve their performance operate jointly rather than separately. We find financial constraints to be the main determinant of most economic measures of performance, for example, profitability and productivity. However, competition is found to increase investment rates as well. Interactive effects are in fact not significant. There are stronger results for the qualitative measures of performance, restructuring, which are found to be significantly influenced by ownership and monopoly power, as well as by financial constraints. There is also evidence for joint determination of performance; restructuring is less in state-owned monopolies while financial constraints are not binding on performance in state-owned firms.

Overall, therefore, the survey indicates that enterprise behaviour was not markedly different in 2000 from 1996, in terms of the ways that economic factors were influencing behaviour. Although the conditions for improved 
performance were beginning to emerge - increased competition, outsider ownership, effective governance - they were not yet having much systematic effect on quantitative measures of performance like profitability. The major role of financial constraints in preventing firms from performing well is also very worrying, given the underdeveloped state of Russian capital markets. An important policy conclusion is that effective reform of capital markets and corporate governance must be implemented to facilitate the flow of funds into the enterprise sector.

However, there were also indications that things may still improve in the future. Restructuring activity is increasing and appears to be determined by the factors predicted by theory - private ownership, competition and good governance - although even this is also constrained by the firm's financial position. Moreover, the underlying structures of the economy, most markedly the ownership pattern, appear to be improving. In the longer term, one might reasonably expect these factors to begin to impact on the traditional financial measures of performance.

\section{REFERENCES}

Bennett, J. 1989: The economic theory of central planning. Blackwell: Cambridge, MA.

Blanchard, O, Dornbusch, R, Krugman, P, Layard, R, and Summers, L. 1991: Reform in Eastern Europe. MIT Press: Cambridge, MA.

Blanchard, O and Kremer, M. 1997: Disorganization. Quarterly Journal of Economics 112: 1091-1126.

Blasi, J, Kroumova, M, Kruse and D. 1997: Kremlin capitalism: privatizing the Russian economy. Cornell University Press: Ithaca, NY.

Boycko, M, Shleifer, A and Vishny, R. 1995: Privatizing Russia. MIT Press: Cambridge, MA.

Brown, D and Earle, J. 2001: Privatization, competition and reform strategies: theory and evidence from Russian enterprise panel data. Discussion Paper No.2758, Centre for Economic Policy Research: London.

Commander, S, Fan, Q and Schaffer, M. 1996: Enterprise restructuring and economic policy in Russia. World Bank: Washington, DC.

Djankov, S and Murrell, P. 2002: Enterprise restructuring: a quantitative survey. Journal of Economic Literature 40: 739-792.

Earle, J and Estrin, S. 1996: Employee ownership in transition economies. In: Frydman, R, Gray, G and Rapaczynski, A. (eds), Corporate governance in transition. Central European University Press: Budapest.

Earle, J and Estrin, S. 1997: After voucher privatization: the structure of corporate ownership in Russian manufacturing industry. Discussion Paper No.1736, Centre for Economic Policy Research: London.

EBRD. 1999: Transition report, 1999: ten years of transition. EBRD: London.

EBRD. 2002: Transition report, 2002. EBRD: London.

Ellman, M. 1989: Socialist planning. Cambridge University Press: Cambridge.

Estrin, S, Gelb, A and Singh, I. 1995: Shocks and adjustment by firms in transition: a comparative study. Journal of Comparative Economics 21: 131-153.

Estrin, S and Wright, M. 1999: Corporate governance in the former Soviet Union: an overview. Journal of Comparative Economics 27: 398-421. 
Gregory, P and Stuart, R. 1986: Soviet economic structure and performance. Harper \& Row: New York. Goskomstat data. 1990-1999: Goskomstat: Goskomstat data Moscow.

Hanson, P. 2002: Barriers to long-run growth in Russia. Economy and Society 31: 62-84.

Ledeneva, A. 1998: Russia's economy of favours. Cambridge University Press: Cambridge.

Megginson, W and Netter, J. 2001: From state to market: a survey of empirical studies on privatization. Journal of Economic Literature 39: 321-389.

Nellis, J. 2000: Privatization in transition economies: what happened? What's next? World Bank: Washington, DC. Mimeo.

Nickell, S. 1996: Competition and corporate performance. Journal of Political Economy 104: 724-746. Portes, R (ed). 1993: Economic transformation in central Europe: a progress report. Centre for Economic Policy Research: London.

Stiglitz, J. 1999: Whither reform? ten years of the transition. ABCDE Conference. World Bank: Washington, DC.

Vickers, J and Yarrow, G. 1988: Privatization: An economic analysis. MIT Press: Cambridge MA.

World Bank. 1996. World development report: from plan to market. Oxford University Press: Washington, DC. 